\title{
CHRZEŚCIJAŃSTWO A BADANIA NAUKOWE
}

\section{Od ttumacza}

Publikowany poniżej tekst Newmana jest częścią pełnego cyklu, ogłoszonego pod tytułem: Idea uniwersytetu (The Idea of a University). Część pierwszą, kojarzącą się najczęściej z tym tytułem, stanowi seria prelekcji, przygotowanych dla audytorium Katolickiego Uniwersytetu w Dublinie. Autor zaczął je tamże wygłaszać w roku 1852. W przekładzie polskim ta część ukazała się w Państwowym Wydawnictwie Naukowym w roku 1991. Należy przy tym dodać, że szereg wydań angielskich obejmuje jedynie dziewięć odnośnych wykładów. Również wersja włoska, którą opracował Luca Obertello (Milano 1976) ogranicza się do tego krótkiego cyklu.

Wiadomo jednak, że Newman, sprawując urząd rektora w tym uniwersytecie, napisal i wygłosił drugi cykl wykładów dla konkretnych wydziałów, zwłaszcza humanistycznych, choć też dla innych, i w związku z tym na tematy bardziej szczegółowe (University Subjects, Discussed in Occasional Lectures and Essays). Duża część wydań angielskich The Idea of a University, w tym krytyczna edycja oksfordzka I. T. Kera z roku 1976, obejmuje oba cykle wykładów (łącznie 19) wraz z jedenastostronicową przedmową (Preface). Poniższy przekład wykładu, przeznaczonego dla Wydziału Nauk Przyrodniczych, a opublikowanego pt. Christianity and Scientific Investigation, należy właśnie do drugiego cyklu wspomnianych wyżej tekstów Newmana.

Jeżeli książkę The Idea of a University w jej krótszej wersji można uważać za manifest uniwersytetów, głównie jako instytucji nauczających i wychowawczych, to prelekcję o badaniach naukowych należy traktować jako manifest swobody w dociekaniu prawdy. Pierwszą reakcją dzisiejszego odbiorcy, świadomego olśniewających, niemal niewiarygodnych postępów nauki, szczególnie technicznej, od czasu wystąpienia Newmana — choć i on zdawał sobie sprawę z mnogości odkryć może być odruch sceptycyzmu i zniecierpliwienia: czy warto jes z c ze sięgać do uwag sprzed 140 lat na taki temat i spodziewać się jakiegoś aktualnego pouczenia? Tymczasem powinno się podejść do rzeczy „od przeciwnego końca”, by podziwiać przenikliwość wielkiego umysłu, który j u ż w połowie epoki wiktoriańskiej dostrzegal istotne pytania ludzkiego umysłu wszystkich czasów w obliczu prawdy i z ogromnym zmysłem syntezy przekraczał trudności czy problemy swoich współczesnych lub wcześniejsze, by wskazywać rozwiązania wyprzedzające dzisiejsze poglądy na naukę, jej sprzeczności wewnętrzne (ostatnio przypomnial je o. J. M. Bocheński OP w wywiadzie ogłoszonym w „Spotkaniach”), jej niezbywalne uprawnienia, a jednak także jej ograniczenia w zetknięciu z Objawieniem.

Nie znaczy to, że ten realistyczny myśliciel, który tak dobrze wiedział o wpływie środowiska i kultury na jednostkę ludzką, w niczym nie podlegał swojemu czasowi. Ten poddany królowej Wiktorii, władającej - można powiedzieć — połową globu ziemskiego porównuje rolę rektora uniwersytetu, rozsądzającego roszczenia poszczególnych nauk, do roli władcy imperium (mówi zresztą o Imperium Romanum, które to zestawienie budzi i budziło dawniej tzw. mieszane reakcje). Zarazem można chyba przypomnieć, że ktoś współczesny i świadomy brytyjskiej wieloświato- 
poglądowości i wielonarodowych organizmów politycznych oczekiwal od rektora uniwersytetu liberalnego i długomyślnego podejścia do rządzenia przedstawicielami różnych dyscyplin („żyj i pozwól żyć" - niżej s. 74). Na terenie polityki w pewnym sensie przewiduje to jakby dzisiejsze uznanie prawa wielu narodów i wielu kultur do samostanowienia, choć nie rozwiązuje to problemów, ba - tuzinów ostrych konfliktów, następujących po rozpadzie imperiów. Na terenie nauki zawarowuje stanowczo autonomię każdej galęzi. W związku z tym rektorskie rozrządzenie nie będzie funkcją siły, a raczej funkcją trafnego sądu rektora. Można tu dodać, że mutatis mutandis to samo odnosiłoby się - niemal a fortiori - do uczonych na kierowniczych stanowiskach w instytutach badawczych, obejmujących różne specjalności. Newman w pełni uznawał potrzebę i wagę takich instytucji, właściwie nie widział w uniwersytecie miejsca dla odkrywczych dociekań, ściśle pojętych. Stanowisko zaskakujące u teoretyka uniwersytetu (por. Preface, s. 82 n., w wydaniu oksfordzkim I. T. Kera).

Omawiany wykład nie rozstrzyga niezwykle trudnego pytania o stosowanie w skrajnych wypadkach przymusu przez władzę, żądania posłuszeństwa; byłoby ono następstwem pozycji rektora, który ki e ru je podległą mu instytucją. Zapewne wielki konwertyta powiedziałby, że liczy na wyrobiony umysł i wyrobione sumienie danej osoby. Świadczy to zarazem wiele o wysokim pojęciu Newmana o ludziach wysuwanych na stanowisko przywódcy w takim układzie. W jakimś sensie i w jakimś stopniu zagadnienie powraca, gdy Newman ocenia, że nie może pominąć pytania o stosunek wolności badania naukowego do niepodważalności autorytetu Kościoła. Bardzo usilnie natomiast przestrzega, by do tego autorytetu sięgać tylko wtedy, gdy jest to naprawdę konieczne, gdy z pewnością nie ma pomyłki lub powierzchowności we wniosku, ich chodzi rzeczywiście o magisterium, że nie ma zbędnego pośpiechu itd. Sam bowiem, jak wiadomo, bywał ofiarą bezpodstawnej nieufności, nawet w Rzymie.

Refleksja wynikająca z wypowiedzi kard. Newmana obejmuje tyle spraw, że o podjęciu wszystkich, a jeszcze mniej o ich wyczerpaniu nie może być mowy. Trzeba tylko ogólnie przypomnieć, że autor The Idea of a University i Grammar of Assent występuje tu w charakterystycznej dla niego roli mędrca, w jakiejś mierze też w roli kapłana o imponująco szerokich horyzontach, uprzedzającego tak znacznie od niego późniejsze postawy dzisiejszych uczonych, a także ludzi Kościoła. Łatwo zauważyć, o ile bliższy jest on niektórym enuncjacjom i linii postępowania dzisiejszego Watykanu niż tego, który był mu współczesny.

Przemysław Mroczkowski

Czas obecny, proszę Panów, to czas, gdy nie tylko na klasyków piśmiennictwa, lecz znacznie bardziej na naukę, w najszerszym znaczeniu tego słowa, kierują się spojrzenia ludzi religijnych wyrażające zaniepokojenie nie całkiem pozbawione słuszności. Skoro uniwersytet, taki jak nasz, deklaruje, że obejmuje wszystkie dziedziny wiedzy i wszystkie działania umysłu, ja zaś ze swojej strony pragnę być w dobrych stosunkach ze wszystkimi przedstawicielami tych kierunków naukowych i z żadnym nie chciałbym się spierać, ba - otwarłbym swoje serce, jeśli nie swój umysł (to wszakże przekracza moje możliwości), na cały obszar prawdy, okazałbym uznanie i gościnność nawet tym studiom, które są dla mnie obce, życząc im powodzenia na drodze rozwoju, przeto więc uczyniwszy wcześniej gesty pojednawcze, naprzód między literaturą piękną a religią, następnie pomiędzy medycyną a teologią, obecnie chciałbym dorzucić sło- 
wo w celu przeciwstawienia się antagonizmowi (zbędnemu, ale od czasu do czasu zarysowującemu się jako fakt) pomiędzy teologami a przedstawicielami — najogólniej mówiąc — nauki.

Sądzę, że w tym miejscu powinienem najpierw wypowiedzieć się obszerniej na temat wspaniałej godności instytucji, którą stać na tak szeroki gest, że dopuszcza omówienie takiego tematu. Wśród celów ludzkich poczynań - a to oświadczenie mogę w pełni uzasadnić — nie da się, proszę Panów, wskazać na cel wyższy lub znakomitszy niż ten, ku któremu się zmierza, zakładając uniwersytet. Powołanie do życia i utrzymanie prawdziwego uniwersytetu oznacza, zgodnie z intencją założycieli, gdy się zrozumie słowo „uniwersytet”, podjęcie jednego z największych dzieł, wielkich przez towarzyszące trudności i swą ważność - dzieła, któremu się oddają najświetniejsze umysły i ludzie najprzeróżniejszych uzdolnień. Przede wszystkim bowiem instytucja ta podejmuje się uczenia wszystkiego, czego należy uczyć w zakresie jakiejkolwiek dziedziny ludzkiej wiedzy i obejmuje w swoim zasięgu najwznioślejsze tematy ludzkiego myślenia oraz najbogatsze pola ludzkiego dociekania. Nie ma rzeczy zbyt obszernej, zbyt subtelnej, zbyt odległej, zbyt drobiazgowej, zbyt logicznie czy dokładnie rozbudowanej, by zajęcie się nią przekraczało możliwości uniwersytetu.

Nie to jednak stanowi podstawę mego domagania się dla tej instytucji aż tak suwerennej pozycji. Objęcie bowiem wszelkich szkół i zakładów naukowych jedną nazwą oraz nadanie im miana uniwersytetu może być, uczciwie rzecz ujmując, zwykłym uogólnieniem, a twierdzenia i deklaracje, że rozwijanie wszelkich rodzajów wiedzy do najdalszych granic wymaga najpełniejszego zaangażowania naszych władz intelektualnych będzie tylko truizmem.

Zasadniczym powodem mej odwagi takiego mówienia o uniwersytecie nie jest fakt, że obejmuje on po prostu cały obszar wiedzy, ale że jest dla niej właściwą dziedziną, jej królestwem; że głosi znacznie więcej niż gotowość otwarcia swoich bram i znalezienia miejsca dla wszelkiej sztuki i nauki, dla całej historii i filozofii na podobieństwo karawanseraju. Prawdę powiedziawszy deklaruje on gotowość do wyznaczenia każdemu rodzajowi studiów należnego mu miejsca i słusznych granic; do określenia odnośnych praw, ustalenia wzajemnych stosunków, stworzenia wzajemnej komunikacji dla wszystkich i dla każdego; do utrzymania w ryzach osoby zbyt ambitne i agresywne, przy jednoczesnym wspomaganiu i podtrzymywaniu tych, którzy od czasu do czasu załamują się przygnieceni popularnością kolegów i innych, do których los bardziej się uśmiechnął; wreszcie do utrzymania pokoju między nimi wszystkimi, by dzielące ich różnice i przeciwieństwa obracać ku wspólnemu dobru. 
Oto dlaczego, proszę Panów, twierdzę, że założenie uniwersytetu jest przedsięwzięciem zarazem trudnym, pełnym mozołu, a także obfitującym w dobrodziejstwa. Zobowiązuje to bowiem do przyjmowania wszystkich zgłaszających się bez obawy, bez uprzedzeń, bez kompromisów, o ile się zgłaszają w imię Prawdy. Trzeba dostosowywać poglądy, doświadczenia i nawyki myślowe najbardziej niezależne i niepodobne do siebie; trzeba dać najpełniejszą swobodę myśli i kształtować w ich najoryginalniejszych przejawach największą siłę wyrazu w najdalej posuniętym zakresie.

Szczególna rola polega tu na ściągnięciu wielu rzeczy w jedność. Uniwersytet uczy się tak postępować nie przez reguły, które można ująć na piśmie, a przez rozwagę, mądrość i wyrozumiałość, wyrastające z głębokiego wglądu w dany temat wiedzy oraz z czujnego powściągania agresji i fanatyzmu w każdym punkcie.

Uważamy za sprawę wielkiej wagi, i słusznie, zaplanowanie i realizację szerokiej organizacji politycznej. Poddać jednej władzy, na sposób starego Rzymu, sto niezgodnych ze sobą ludów, zachować w każdym z nich w słusznym zakresie realizację jego przywileju, pozwolić na rozkwit uczuć narodowych i działanie bodźca współzawodniczenia, jednocześnie zaś prowadzić ich do spojenia w jednym układzie społecznym i związać w trwałą imperialną potęgę — to osiągnięcie, w którym zawiera się znamię geniusza rasy je podejmującej. Tu regere imperio populos, Romane, memento. Była to, jak ją widział poeta, ta szczególna chluba Rzymianina, zdolna dorównać na swój sposób tej drugiej chlubie, która należała się Grekom; u nich wyrastała ona $\mathrm{z}$ językowo-literackiego mistrzostwa, obfitej nad miarę płodności myślenia wraz z kunsztem i dystynkcją w znalezieniu dla niego wyrazu.

Czym imperium w historii politycznej, tym jest uniwersytet $w$ dziedzinie filozofii i naukowego badania. Jest on, jak mówiłem, władzą opiekuńczą wszelkiej wiedzy i nauki, faktu i zasady, dociekania i odkrycia, eksperymentu i spekulacji; on kreśli mapę obszarów intelektu i pilnuje, by granice każdej dziedziny wiedzy były najskrupulatniej przestrzegane i by z żadnej strony nie zagrażała aneksja ani zbytnia uległość. Działa jak sędzia na sportowych zawodach, rozstrzygając między jedną a drugą prawdą, biorąc pod uwagę naturę i ważność — każdej z nich, wyznacza wszystkim kolejność pierwszeństwa. W swej działalności nie preferuje żadnej pojedynczej dziedziny myśli, choćby najszerszej i wysokiej rangi, żadnej też nie poświęca na rzecz innych. Okazuje szacunek i lojalność stosownie do ważności każdej dziedziny nauki, okazuje go roszczeniom studiów literackich, badaniom przyrodniczym, historycznym, metafizycznym, teologicznym. W stosunku do wszystkich zachowuje bezstronność i udziela pomocy każdemu na jego właściwym obszarze i dla właściwego mu celu.

Bez wątpienia zajmuje pozycję służebną wobec Kościoła katolickiego. W taki sam sposób jeden z sędziów, powołanych przez królową, jest urzędni- 
kiem z jej ramienia, a jednak określa i przeprowadza prawne postępowanie między królową a jej podwładnymi. Wobec Kościoła katolickiego jest instancją wykonawczą: po pierwsze dlatego, ponieważ tylko tym może być prawda jakiegokolwiek rodzaju wobec prawdy; po drugie, co jest ważniejsze, ponieważ natura zawsze będzie hołdownicza w stosunku do łaski, rozum zaś nie może działać inaczej niż wyjaśniając i broniąc Objawienie; po trzecie, ponieważ Kościół ma władzę najwyższą, więc przemawia ex cathedra, należy mu się posłuszeństwo. To jednak jest daleki cel uniwersytetu; jego cel bezpośredni (z jakim mamy tu wyłącznie do czynienia) to zapewnienie odpowiedniego porządku w zgodności $\mathrm{z}$ jednym najwyższym ładem i dbałością o zachowanie wszystkich jego działów i metod myślenia, jakie stworzył ludzki intelekt.

W tym punkcie poszczególni profesorowie są jak ministrowie reprezentujący różne polityczne władze na jednym dworze lub na jednej konferencji. Są oni przedstawicielami odnośnych nauk i dbają o ich interesy, każdy na swoim odcinku. W razie sporu między tymi naukami powinni go przedyskutować i sprawę uzgodnić, tak by nie groziły wykraczające ponad normę roszczenia z którejkolwiek strony, ani wzburzenie w otwartym konflikcie czy zamieszki na szerszą skalę. Filozofia liberalna staje się w tych warunkach nawykiem umysłowości praktykujących takie rozstrzygnięcia. Szerokie, swobodne podejście w myśleniu sprawia, że zbiegają się linie, na pozór równoległe, w odpowiadającym ludziom momencie, a zasady, uznane za niewspółmierne, pozostają antagonistyczne, nie zagrażając niczemu.

\section{III}

Tu, proszę Panów, rozpoznajemy specyficzny charakter filozofii, o której mówię, jeżeli filozofią zwać ją należy w przeciwieństwie do ścisłego ujęcia nauki lub systemu. To, czego uczy, nie opiera się na jednej idei, nie da się sprowadzić do określonych formuł. Newton mógł odkryć wielkie prawo ruchu w świecie fizycznym i klucz do wyjaśnienia dziesięciu tysięcy zjawisk i podobne sprowadzenie złożonych faktów do prostych zasad może okazać się rzeczą do pomyślenia w innych działach natury, ale całego wielkiego wszechświata, moralnego i materialnego, podlegającego zmysłom i nadprzyrodzonego, nie można wyliczyć i wymierzyć, choćby do tego zabrał się nawet największy z ludzkich umysłów, a jego części składowe można porównywać i dostosowywać do siebie, ale nie można ich mieszać. Oto punkty odnoszące się wprost do tezy, jaką sobie założyłem, gdy zaczynałem niniejszy wykład, a do którego zdążam we wszystkim, co powiedziałem lub jeszcze powiem.

Dostrzegając to, proszę Was, Panowie, o zachowanie w pamięci, że ta filozofia umysłu imperialnego, to za taki uważam umysł działający w uniwersytecie, opiera się nie tyle na uproszczeniu, co na rozróżnieniu. Prawdziwy jej 
przedstawiciel raczej określa, niż analizuje. Jego celem nie jest kompletne skatalogowanie czy interpretacja przedmiotów wiedzy ale raczej pójście, na ile to dla człowieka możliwe, za tym, co w swojej pełni pozostaje tajemnicze i niezmierzone. Traktując jako swoje zadanie zajęcie się wszystkimi naukami, metodami, zbiorami faktów, zasad, doktryn, prawd, stanowiących odbicie wszechświata w ludzkim intelekcie, dopuszcza je wszystkie, nie ignoruje żadnej, a nie ignorując żadnej nie pozwala również żadnej na przekroczenie jej granic i wynoszenia się nad inne. Jego hasłem jest: żyj i pozwól żyć. Bierze rzeczy jakimi są. Poddaje się wszystkim w należnych im granicach: przyjmuje nienaruszalne linie demarkacyjne, które przebiegają między podmiotem a przedmiotem; obserwuje jak osobne prawdy układają się wzajemnie do siebie, gdzie się zbiegają, a gdzie się rozchodzą i posunięte zbyt daleko, w ogóle przestają być prawdami. Jego zadanie to ustalenie stopnia możliwości poznania naukowego w każdej dziedzinie myśli zarówno wtedy, kiedy musimy się zgodzić, że nie będziemy wiedzieli, w którym kierunku prowadzone dociekanie jest bezowocne lub przeciwnie - nader obiecujące, a także gdzie układa się w spirale nie do rozwikłania przez rozum, gdzie wchłania je tajemnica, gdzie pogrąża się w otchłań. Oczekuje się od umysłu dobrej znajomości znaków trudności, prawdziwych i pozornych, metod właściwych poszczególnym tematom i dyscyplinom, orientacji w tym, jakie są granice racjonalnego sceptycyzmu, w każdym szczegółowym wypadku, a jakie są żądania wiary zdecydowanej i ostatecznej. Jeżeli ma jakąś kardynalną maksymę w swojej filozofii, to brzmi ona, że prawda nie może być w sprzeczności z prawdą; jeżeli zaś ma jakąś inną maksymę, to prawda często wydaje się przeciwna prawdzie, a jeżeli trzecią, będzie to praktyczny wniosek, że przy takich pozorach musimy zachować cierpliwość i nie spieszyć się z głoszeniem poglądu, iż ważkość ich jest ogromna i budzi obawę.

Sam ogrom systemu rzeczy wszystkich, podlegających ludzkiemu zapisowi, stanowi uzasadnienie tej cierpliwości i ostrożności. Ten bowiem ogrom nasuwa myśl, że przeciwieństwa i tajemnice, które umysł napotyka w różnych naukach, mogą być po prostu następstwami naszego w nieunikniony sposób niedoskonałego pojmowania. Jest tylko jedna myśl większa od myśli o wszechświecie: jest nią myśl o jego Stwórcy. Jeżeli na chwilę, proszę Panów, odchodząc od głównego biegu mojej myśli, przypominam naszą wiedzę o Bycie Najwyższym, to czynię to w tym celu, by zaczerpnąć z niej ilustrację odnoszącą się do mojego tematu. On choć Jeden, jest jakby światem światów w sobie, rodząc w naszych umysłach nieokreśloną liczbę odrębnych prawd, z których każda jest niewyrażalnie bardziej pełna tajemnicy niż cokolwiek, co da się znaleźć w tym wszechświecie przestrzeni i czasu. Każda poszczególna Jego cecha, rozważana w sobie, jest przdmiotem niewyczerpanej nauki. Próba zaś pogodzenia ze sobą którychkolwiek dwóch czy trzech takich cech jak: miłość, potęga, sprawiedliwość, świętość, prawda, mądrość - stanowi cenny materiał dla wieczystej kontrowersji. Potrafimy pochwycić sens i przyjąć do świadomości każdą boską cechę 
w jej formie elementarnej, a przecież nie zdołamy ogarnąć tych cech w ich nieskończoności ani w nich samych czy w połączeniu jednych z drugimi. Jednakże nie przeczymy pierwszej dlatego, że nie można jej w doskonały sposób pogodzić $\mathrm{z}$ drugą, ani drugiej - ponieważ pozostaje w pozornym przeciwieństwie z pierwszą i trzecią. To samo zachodzi z kolei na płaszczyźnie Jego stworzenia, materialnego i moralnego. Najwyższa mądrość polega na przyjęciu prawdy jakiegokolwiek rodzaju, gdziekolwiek da się jasno stwierdzić, że jest ona taką, choćby rysowała się trudność w zgraniu jej z inną znaną prawdą.

Łatwo wskazać na maksymalne przeciwieństwo jednych idei do innych narzucanych nam przez kontemplację wszechświata, domagając się przyjęcia $\mathrm{z}$ naszej strony jako rzecz oczywistą, że nie ma niczego nieracjonalnego w pogodzeniu się z niezaprzeczalnym brakiem zgodności, na który wskazujemy, nazywając go pozornym, tylko dlatego, że gdyby nie był pozorny, a rzeczywisty, to dwie sprawy wspólistnieć by nie mogły. Tak się ma rzecz na przykład z kontemplacją przestrzeni: nie możemy przeczyć jej istnienia, choć jej idea w żadnym wypadku nie może znaleźć sobie miejsca — jeśli się wolno tak wyrazić w naszych umysłach; nie możemy powiedzieć, że w jakimkolwiek punkcie osiąga ona swój kres, a zaś z kolei staje się niezrozumiałe powiedzenie, że wybiega przed siebie nieskończenie. Wydaje się zaś pozbawione sensu, jeśli powiemy, że nie istnieje ona, aż zaczną ją wypełniać jakieś ciała i powiększa się w zgodności z jakimś przypadkiem.

A teraz przykład czasu. Nie zdołamy wymyśleć jakiegoś początku dla niego, by się nie zapytać, co było przed tym początkiem, a przecież brak jakiegokolwiek początku, choćbyśmy dowolnie daleko posunęli się wstecz, staje się po prostu czymś nie do pojęcia. Również tutaj, jak w przypadku przestrzeni, nie przychodzi nam nawet na myśl przeczyć istnieniu czegoś, czego zrozumienie całkowicie przekracza nasze możliwości.

Przechodząc teraz od tych wysokich rejonów myśli (ta zaś choć tak wysoka, potrafi przecież absorbować nawet dziecko w jego kontemplacji) do wzajemnego oddziaływania duszy i ciała, stajemy wobec niedających się pogodzić spraw, których ani nie możemy odrzucić, ani wytłumaczyć. Jak się to dzieje, że wola potrafi poddać swemu działaniu muskuły, to pytanie, którego nacisku doświadczyć może nawet dziecko, ale nie znajduje odpowiedzi na nie żaden badacz doświadczalny.

Dalej, gdy kontrastujemy fizyczne i społeczne prawa, jakim podlega człowiek tu na ziemi, musimy przyznać, że nauka o naturze i nauka społeczna są ze sobą w kolizji. Człowiek jest stworzeniem fizycznym i stworzeniem społecznym, a nie może jednocześnie zrealizować swojego fizycznego i społecznego celu do końca; zmuszony jest poświęcić częściowo jeden lub drugi. Gdybyśmy byli na tyle szaleni, by puszczając wodze naszej wyobraźni dopuścić istnienie dwóch stwórców, $z$ których jeden byłby autorem naszej strony zwierzęcej, inny zaś społeczeństwa, wtedy istotnie moglibyśmy zrozumieć, jak się to dzieje, że 
pełna wysiłku praca umysłu i ciała, pożyteczne umiejętności, obowiązki męża stanu, rządzenie i tym podobne sprawy, wymagane przez system społeczeństwa, wyniszczają tak bardzo zdrowie, życie i pomniejszają radość z niego. Innymi słowy znaczy to, że nie możemy odpowiednio uzasadnić istniejących i niezaprzeczalnych prawd inaczej, jak na zasadzie hipotezy zakładającej coś, co czujemy jako absurd.

Nie inaczej jest w nauce matematycznej, gdzie jak często podkreślano, filozof musi cierpliwie godzić się z obecnością prawd, które nie tracą swojej prawdziwości przez fakt, że nie mogą się ze sobą wzajemnie zgodzić. Mówi się o istnieniu nieskończonej ilości krzywych, które są w możności dzielić przestrzeń w taki sposób, iż żadna prosta, choć jest ona długością bez szerokości, nawet wejść tam nie może. Mówią mu również o pewnych liniach, wciąż się do siebie zbliżających, których wzajemna od siebie odległość ma wartość skończoną, a które jednak nigdy się nie spotkają. I musi on znosić, jak zdoła najlepiej, te pozorne sprzeczności, nie próbując przeczyć istnieniu prawd, które się złożyły w odnośnej wiedzy na te pozorne sprzeczności.

Niech mi teraz będzie wolno, moi Panowie, zwrócić waszą uwagę na to, co pragnąłbym podsunąć jako wniosek z powyższych znanych faktów. Będzie mi chodzić o to, aby wskazać na argument typu a fortiori. Skoro wykazujecie ciągle tyle wzorowej cierpliwości w zetknięciu się z niewytłumaczalnymi prawdami w tylu dziedzinach wiedzy, ludzkiej i boskiej, jeśli traktować te dziedziny każdą odrębnie, i dalej - skoro nie okazujecie od razu oburzenia, postawy cenzorskiej, podejrzliwości, niedowierzania, gdy stwierdzicie, że w naukach świeckich jedna prawda jest nie do pogodzenia (wedle naszego ludzkiego umysłu) z inną prawdą, albo niezgodna ze sobą samą, to nie dopuścicie również myśli, że szczególnie trudne do zniesienia byłoby to, gdyby wam powiedziano, iż tu czy tam pojawia się, nie powiem, trudność nierozwiązywalna, zdumiewające przeciwieństwo, tym bardziej nie powiem - sprzeczność między oczywistymi faktami podawanymi z jednej strony przez Objawienie, $z$ drugiej przez naturę, ale nawet zgrzyt, niejasność, rozbieżność tendencji, czasowy antagonizm, różnica tonu między jednym a drugim źródłem, to znaczy z jednej strony między poglądem katolickim a z drugiej strony — astronomią, geologią, fizjologią, etnologią, ekonomią polityczną, historią, archeologią. A więc powiadam, że skoro świadomie, jako katolicy godzimy się z tym, że Boska jedność zawiera w sobie przymioty, które w odbiorze naszych skończonych umysłów jawią się częściowo jako sobie wzajem przeciwne; skoro świadomie godzimy się, że w objawionej Boskiej naturze są rzeczy, wprawdzie nieprzeciwne rozumowi, ale nieskończenie dziwne dla wyobraźni; skoro w Jego dziełach nie możemy 
ani odrzucić, ani przyjąć idei przestrzeni i czasu oraz koniecznych właściwości linii prostej, nie cierpiąc przy tym udręki czy wręcz tortury - wobec tego, proszę Panów, nie wyrażam tak naprawdę jakiejś niesłychanej prośby, jeżeli w imieniu uniwersytetu wysuwam żądanie skierowane do osób wypowiadających się pisemnie na tematy religijne, do prawników, ekonomistów, fizjologów, chemików, geologów i historyków, by posuwali się naprzód spokojnie, po dobrosąsiedzku w przynależnych im koleinach spekulacji, badań i eksperymentów, z pełną wiarą w spójność tej wielokształtnej prawdy, której obszar jest między nich podzielony, szlachetnie ufając, że ostatecznie okażą się zgodni, pojedynczo i zbiorowo w swych połączonych wynikach, choć mogą występować chwilowe kolizje, pozory budzące pewne zaniepokojenie, liczne obawy o następstwa spraw, zapowiedzi przeciwieństw i zjawiska zawsze trudne do wyobrażenia, ale - powiadam - nie dla rozumu. Nie wchodzi tu w grę prośba, łącząca się z wielkimi wymaganiami pod ich adresem, skoro muszą przyjmować istnienie tajemnic w prawdach Objawienia, percypowanych na swoim odcinku i w prawdach rozumu, by zachować spokój, by żyć wzajemnie wedle nakazów dobrej woli, by zachować spokój umysłu, jeżeli przy porównaniu natury i Objawienia występują rozbieżności nie w końcowym wyniku, ale w rozumowaniach, okolicznościach, skojarzeniach, przewidywaniach, przypadłościach związanych z ich szczegółowym nauczaniem.

Jest rzeczą konieczną i to w najwyższym stopniu, by podkreślić tę sprawę z całą powagą i energią, ze względu na protestantów, gdyż mają oni nader osobliwe o nas mniemanie. Mimo że świadectwo historii dowodzi czegoś zgoła przeciwnego, twierdzą oni, że Kościół nie ma innej metody stłumienia błędu aniżeli posługując się zbrojnym ramieniem lub zakazując badań. Rzucają nam wyzwanie, byśmy założyli „Szkołę Badań Naukowych” i dalej ją prowadzili. Ze względu więc na nich muszę temu zagadnieniu poświęcić więcej uwagi. Twierdzę przeto, że kto przyjmuje Objawienie $\mathrm{z}$ tą absolutną wiarą, jaka jest znakiem wyróżniającym i przywilejem katolika, nie jest od razu podekscytowaną nerwowo postacią, podrywającą się na każdy nagły odgłos i zaczynającą drżeć na widok wszystkiego, co niezwykłe lub nowe. Nie żyje w lęku, owszem — potrafi się uśmiechnąć $\mathrm{z}$ takiego pomysłu, że jakaś inna metoda naukowa może przynieść odkrycie, które zaprzeczy jakiemuś dogmatowi jego religii. Wie on doskonale, że bez wyjątku każda nauka w trakcie swego rozwoju może stanąć na drodze rozwoju innych nauk, choć nie było z jej strony żadnej takiej intencji; i wie również to, że jeśli istnieje jakaś konkretna nauka, która z racji swojej pozycji, suwerennej i zabezpieczonej przed wszelkim atakiem, może ze spokojem znosić takie niezamierzone kolizje ze strony synów tej ziemi, to jest nią teologia. Jest on pewny i nic jego pewności nie podważy, że jeśli coś się wydaje udowodnione przez jakiegoś astronoma, albo etnologa, to odnośna teza okaże się ostatecznie po pierwsze nieudowodniona, po drugie - niesprzeczna 
z Objawieniem, lub - po trzecie — niesprzeczna z autentyczną treścią Objawienia, natomiast sprzeczna z czymś, co przyjęto mylnie za jego treść.

Jeśli zaś chwilowo wydaje się to sprzeczne, on jest gotów poczekać, wiedząc, że błąd jest jak ci wszyscy, którzy przekroczyli prawo: wystarczy dać mu wystarczająco długi sznur, a okaże się, że jest bardzo skłonny do samobójstwa. Nie twierdzę, że nasz cierpliwy abserwator uchyli się od udzielenia zachęty i czynnej pomocy w oczekiwanym samobójstwie: on nie tylko udzieli błędowi wystarczającej długości sznura, lecz także pokaże, jak się ze sznurem obchodzić; poruczy całą sprawę rozumowi, refleksji, trzeźwemu osądowi, zdrowemu rozsądkowi i czasowi, powołanemu do wyjaśnienia tak wielu sekretów. Zamiast by miał go poirytować chwilowy triumf wrogów Objawienia (jeśliby z takim poczuciem triumfu miało się do czynienia), zamiast przyśpieszać par force rozwiązanie trudności, które ostatecznie może zamienić proces badawczy w nierozplątywalny kłębek, nasz widz umiejący odczekać, przypomni sobie, że zgodnie ze zrządzeniem Opatrzności nasze pozorne niebezpieczeństwa okazują się często największymi wygranymi, jak w słowach protestanckiego poety:

Chmury, co lęku są przyczyną,

Miłosierdzem są brzemienne,

Błogosławieństw deszczem na nas spłyną.

Jako rzecz oczywistą przytoczę pewien aż nadto dobrze znany przykład. $\mathrm{Z}$ chwilą gdy system kopernikański zaczął się upowszechniać, czyż religijnie myślącego człowieka nie ogarniało uczucie niepewności i niepokoju lub przynajmniej obawa zgorszenia wobec pozornej sprzeczności, ujawniającej się wobec pewnej autorytatywnej tradycji Kościoła w tym, co stwierdzało Pismo św.? Panowało powszechne przeświadczenie, tak jak gdyby apostołowie expressis verbis podali to w słowie i w piśmie, że zgodnie z prawdą Objawienia ziemia jest nieruchoma, a słońce, tkwiące na solidnym firmamencie, wokół ziemię obiega. Jednakże po niedługim czasie i po pewnym rozważeniu spraw śtwierdzono, że Kościól niczego prawie nie przesądził w kwestiach tego rodzaju i że nauka fizyki może poruszać się w tej dziedzinie myśli niemal z całkowitą swobodą, nie lękając się natknięcia na decyzje władzy kościelnej. Otóż prócz ulgi, jaką to przyniosło katolikom, gdy zdali sobie sprawę, że ten dodatek do ich licznych, już istniejących kontrowersji, został im oszczędzony, był to poniekąd w tej sytuacji argument za boskością ich religii. Zasługuje to bowiem na szczególną uwagę, gdy się zważy, jak szeroko i przez jak długi czas jedna określona interpretacja fizycznych twierdzeń, zawartych w Piśmie św., była przez katolików przyjmowana, że Kościół formalnie jej nie potwierdził. Patrząc na sprawę z ludzkiego punktu widzenia, było nieuniknione, że Kościół przyswoi sobie tę 
opinię. Teraz wszakże stwierdzamy, poznawszy naszą pozycję wobec nowych nauk naszego czasu, że pomimo bogactwa komentarzy, od samego początku ciągle formułowanych przez Kościół na temat tekstu natchnionego, zgodnie ze swoim prawem i obowiązkiem, nie posunął się nigdy do formalnego wyjaśniania wspomnianych tekstów czy do nadania im autorytatywnego znaczenia, które nowoczesna nauka może kwestionować. Uniknięcie zaś tego fatalnego obrotu spraw nie było zwykłym przypadkiem, było raczej wynikiem czujnej opieki Opatrzności. Świadczy chyba o tym epizod z historii samych „ciemnych wieków”. Gdy wspaniały św. Bonifacy, apostoł Niemiec, wielki świętością, a nie wiedzą świecką, skarżył się Stolicy Świętej, że św. Wirgiliusz naucza o istnieniu Antypodów, Stolica Swięta skorzystała ze „wskazówki z góry”, jak ma postąpić; nie wypowiedziała się za irlandzkim filozofem, co by oznaczało zajęcie stanowiska poza swoją kompetencją, ale przeszła milcząco ponad opinią filozoficzną w materii nie podpadającej Objawieniu.

Czasy poszły naprzód, wkroczył nowy stan rzeczy w dziedzinie intelektualnej i społecznej. Do dyspozycji Kościoła stanęła władza doczesna. Kaznodzieje spod znaku św. Dominika rośli we wpływy. Teraz, zważywszy jak długi czas upłynął, możemy pytać z zaciekawieniem, czy Kościół zmienił swoją prastarą zasadę postępowania i potępił działalność intelektualną. Wprost przeciwnie. Jesteśmy w prawdzie epoce uniwersytetów: oto klasyczny czas scholastyków; oto wspaniały i najwyższy przykład mądrej strategii i szerokiego liberalizmu Kościoła, gdy chodzi o dociekania filozoficzne. Jeżeli można gdzieś znaleźć okres, gdy intelekt działał bez jakichkolwiek hamulców, pozwolił sobie na swobodę, to tak właśnie było w owym okresie. Czy widziano kiedykolwiek bardziej posunięte folgowanie ciekawości, bardziej „wścibską”, bardziej śmiałą, ostrą, przenikliwą, mocną, racjonalistyczną działalność rozumu, niż wtedy? Jakiejż kategorii, kwestii nie poddawał drobiazgowej analizie ten zmysł subteIny i metafizyczny? Jakąż przesłankę przepuszczono bez jej zbadania? Jakaż zasada nie była śledzona aż do swoich wyjściowych założeń i ukazywana w całej swojej nagości? Jakiż całościowy system nie był poddany analizie? Jakaż złożona idea nie była najdrobiazgowiej tropiona i jakby delikatnie odmalowana, by umysł mógł ją kontemplować, aż rozłożono ją na najmniejsze cząstki $\mathrm{z}$ taką subtelnością i doskonałością wykonania, z jaką mikroskop ukazuje żabią łapkę? Cóż z tego - powtarzam - że występowało tu coś, co nieco bardziej zbliżało się do teologii niż badania przyrodnicze. Ponad wszelką wątpliwość Arystoteles był wtedy poważniejszym przeciwnikiem niż później Bacon. A czy Kościół uciekł się wówczas do użycia siły w stosunku do filozofii? Nie uczynił tego, mimo że filozofia ta była metafizyczna. Był to czas, gdy Kościół dysponował władzą doczesną i mógł wytępić ducha dociekań, a przecież postanowił pokonać go argumentem i rzekł: „W tej rozgrywce jest dwóch uczestników, a mój argument jest lepszy". Wysłał swoich polemistów na arenę filozoficzną. Dominikańscy i franciszkańscy doktorzy, z których największy był św. 
Tomasz, rozegrali bitwę Objawienia pogańskim orężem. Nie chodziło o to, czyj był oręż: prawda pozostawała prawdą na całym świecie. Oślą szczęką, szkieletem filozofii z pogańskiej Grecji Samson scholastycznych szkół przegnał swój tysiąc Filistynów.

W tym miejscu zwróćcie uwagę, Panowie, na zarysowujący się między Kościołem, któremu przysługuje dar mądrości, a nawet najzdolniejszymi, najmądrzejszymi, najbardziej świątobliwymi jego dziećmi. Tak jak św. Bonifacy pozazdrościł swemu współczesnemu koledze spekulacji w dziedzinie nảuki przyrodniczej, tak wcześni Ojcowie okazali maksymalną awersję wobec wielkiego pogańskiego filozofa, świeżo wymienionego - Arystotelesa. Nie wiem, czy jakiś z nich potrafiłby go tolerować. Kiedy zaś w średniowieczu pojawili się tacy, którzy gotowi byli opowiedzieć się za nim, przy czym intencje ich były podejrzane, podjęto energiczny wysiłek, by przepędzić Arystotelesa poza obszar chrześcijaństwa. Tymczasem Kościół zachował milczenie; wypowiedział się ogólnie również niewiele, jak w wyjaśnianiu znaczenia pewnych tekstów Pisma św. o charakterze kosmologicznym.

Od Tertuliana i Caiusa do dwóch Grzegorzów z Kapadocji, od nich do Anastazego Synaity, od tego aż do szkoły paryskiej — imię Arystotelesa było czymś obraźliwym; w końcu św. Tomasz kazał mu rąbać drwa i nosić wodę dla Kościoła. Krzepki z niego niewolnik, a Kościół udzielił swojej sankcji na użycie w teologii idei i słownictwa jego filozofii.

Jeśli zatem — wyrażając się najkrócej — tak bezpieczną rzeczą w dziedzinie religijnej jest owa swobodna dyskusja, a raczej tak bardzo pożądana, to również jest ona niezbędna dla postępu w nauce, przeto położę teraz nacisk na tę stronę tematu. Oświadczam więc, że sprawą pierwszorzędną dla uprawiania odnośnych nauk, w których umysł ludzki osiąga prawdę jest to, by badacz był wolny, od wszystkiego niezależny, nieskrępowany w swoich poczynaniach; by było mu wolno i by mu umożliwiono skupić bez przeszkód całą siłę swego umysłu wyłącznie na jego własnym przedmiocie dociekania, tak aby mu nie groziło, że w procesie i w postępie jego badań będą mu przeszkadzać co chwilę zarzuty zbytniej śmiałości czy ostrzeżenia, że posuwa się za daleko i może kogoś czymś zgorszyć. Ale mówiąc w ten sposób, czuję się zmuszony podać szereg wstępnych wyjaśnień, by uniknąć nieporozumień.

Po pierwsze więc, proszę Panów, co do fundamentalnych zasad religii i moralności, a także co do fundamentalnych zasad chrześcijaństwa lub tego, co się nazywa dogmatami wiary, co do tego podwójnego credo, naturalnego i objawionego, nikt z nas nie powinien twierdzić, że stanowią one jakiekolwiek więzy dla intelektu, gdy traktuje on je jako nienaruszalne. Istotnie, katolik nie może 
ich swym umysłem odrzucić; one zaś również mało przeszkadzają działaniu jego umysłu, jak prawa fizyki jego ruchom fizycznym. Swiadoma percepcja tych praw, która jest jego przyzwyczajeniem, stała się dlań drugą naturą, tak jak prawa optyki, hydrostatyki, dynamiki są niewidzialnymi założeniami, traktowanymi przez katolickiego uczonego jako coś oczywistego w używaniu własnych organów cielesnych. Nie sądzę, by istniał jakikolwiek konflikt z dogmatem; mówię tylko o poglądach teologów albo tych dawniejszych szerokich kręgów paralelnych utrzymujących jakoby słońce krążyło wokół ziemi, albo że ostatni dzień naszych dziejów już nadchodzi, lub też, iż św. Dionizy Areopagita jest autorem dzieł, noszących jego imię.

Po wtóre, nawet jeżeli w grę wchodzą takie opinie, nie przypuszczam jakiegoś wtargnięcia wprost na pole religii, albo żeby jakiś wykładowca nauki faktycznie sformułował jakieś prawo w dziedzinie religii. Gdyby jednak coś takiego miało miejsce, to mogłaby tu wchodzić w grę niezamierzona kolizja $\mathrm{z}$ rodzaju tych, które się trafiają w dyskusji podjętej na jeden $\mathrm{z}$ własnych tematów danego badacza. Byłoby wielkim błędem ze strony kogoś takiego proponować jakieś wnioski filozoficzne lub historyczne jako formalną interpretację Pisma św., co — jak wiadomo - uczynił Galileusz: zamiast się zadowolić głoszeniem swojej nauki o ruchu ziemi jako wnioskiem naukowym i pozostawić na boku porównywania jej z Biblią, on w tej ostatniej kwestii wyręczył tych, do których ta sprawa należała. I trzeba przyznać, Panowie, że zdarzają się dość liczne przykłady takiego błędnego postępowania, ale nie ze strony ludzi nauki, ale ludzi religijnych, którzy powodowani nerwową niecierpliwością, by Biblia nie okazała się niezgodna z wynikami jakiejś najnowszej spekulacji, wciąż występują z geologicznymi lub etnologicznymi komentarzami Pisma św., które muszą zmieniać lub zarzucać zanim dobrze wyschnie atrament, gdyż zmiany w postępie nauki, którą z taką gorliwością przywołali na pomoc, są nader szybkie.

Wreszcie po trzecie, podkreślam, że gdy głoszę tezę o niezależności filozoficznego myślenia, to nie mówię wcale o żadnym for ma ln y m na u czaniu, ale o dociekaniach, rozważaniach i dyskusjach. Jestem jak najdalszy od godzenia się $\mathrm{w}$ jakiejkolwiek materii, nawet graniczącej z religią, na to, co wybitny protestancki teolog nazwał, w odniesieniu do najbardziej świętych przedmiotów, „swobodą prorokowania”. Nie zamierzam degradować profesorów nauk ścisłych, którzy powinni być prorokami Prawdy, do roli publicystów popularyzujących niedowarzone wymysły czy idee notorycznie absurdalne. Nie upominam się również o to, by rozgłaszali jak popadnie wśród swoich słuchaczy najnowsze podszepty fantazji albo nawet by to, co ma w sobie podstawę prawdy, było przez nich nauczane błyskotliwie, jakby od niechcenia, wśród grupy młodzieńców, którzy może ich nawet nie będą słuchać przez sześć kolejnych wykładów, a poniosą na szerokie szlaki ojczyzny mglistą ideę niedopieczonych teorii jakiegoś ambitnego umysłu. 
Powiedzmy raz jeszcze, kierując się sugestią ostatniej myśli, że bardzo trzeba się starać, by uniknąć zgorszenia i wstrząsu przeciętnej inteligencji, podważenia założeń, którymi żyją ludzie słabi; sąsiedztwo prawdy i błędu bywa tak bliskie w poszczególnych umysłowościach, że jest niemożliwe wykorzenić to drugie bez jednoczesnego wyrwania z tym pierwszego, czyli pszenicy. Jeżeli więc istnieje szansa, że jakaś aktualna opinia religijna zostanie w jakiś sposób skompromitowana w trakcie badania naukowego, jest rzeczą słuszną prowadzić takie badania, nie w efemerycznych publikacjach miernej wartości, wpadających w ręce ludzi niedbałych i niewykształconych, ale w dziełach poważnych i rzeczowych, będących odpowiednikiem średniowiecznej dysputy filozoficznej. One wszak, w odpowiednim oddaleniu od kół popularnych myśli i uczuć, niezmiernie przyczyniły się do precyzji teologicznej przez swojego ducha nieustannej energii w dociekaniu naukowym i to pomimo swych wybryków.

\section{VII}

Nie zakładam przeto, że badacz naukowy (1) wchodzi w kolizję z dog m a t a mi, ani (2) że będzie się zabierał na bazie swoich dociekań do jakiejkowiek interpretacji Pisma św. czy do innych wniosków w dziedzinie religii, ani (3) że będzie włączał w swoje nauczanie, nawet na obszarze własnej nauki, paradoksów religijnych, gdyż jego zadaniem jest dociekanie i stawianie wniosków naukowych, ani wreszcie, że nie licząc się z następstwami, będzie gorszył słabych czy maluczkich. Dokonawszy jednak powyższych wyjaśnień nadal twierdzę, że w dziedzinie nauki badacz lub myśliciel nie podlega konieczności prowadzenia swych dociekań przy jednoczesnym sprawdzaniu ich przebiegu w świetle maksym jakichś szkół naukowych czy tradycji popularnej albo w świetle nauki innej niż jego własna; nie musi on wciąż drobiazgowo śledzić, co owe nauki, leżące poza obszarem jego zainteresowań mają mu do powiedzenia, nie musi wciąż odpowiadać heretykom albo niedowiarkom czy zabiegać o postawę budującą. Jest przecież ufny, bo tak go ustawia szlachetny impuls wiary, że choć kierunek jego dociekania może odchylać się to w tę to w inną stronę, posuwać się do przodu lub cofać w swym biegu, albo zagrażać chwilową kolizją jakiemuś innemu kierunkowi badań, czy to teologicznym czy innym, to jednak, jeśli zostawi rzeczy ich biegowi, sprawa przybierze bez wątpienia właściwy obrót, bo prawda zaiste nie może sprzeciwiać się prawdzie i dlatego to, co na pierwszy rzut oka wydaje się „exceptio”, w rezultacie jak najbardziej „probat regulam”.

Jest to dla niego sprawa niezmiernie ważna. Jeżeli nie może podjąć badań podstawowych w zgodności ze specyfiką swej naukowej dziedziny, to w ogóle nie może badań podejmować. Istnieje bowiem prawo, wedle którego umysł ludzki działa, dociekając prawdy, a osiągając ją, rozwija się zgodnie z procesem, 
mającym wiele etapów i postępującym szlakiem okrężnym. Nie ma skrótowej drogi do wiedzy; ani droga w jej kierunku od razu ten właśnie kierunek ukazuje, ani też w momencie początkowym widzimy zawsze ów cel.

Szlak, o którym tu mowa, może często robić wrażenie, jakby się oddalał od punktu dojścia, a jednak wkrótce będzie gładko ku niemu prowadził, jeżeli tylko zdobędziemy się na to, by się go cierpliwie i z determinacją trzymać. Jeżeli zaś etyka poucza nas, że osiągamy złoty środek przez zachowanie dystansu w stosunku do obu skrajności, to w badaniu naukowym nie jest bynajmniej paradoksem, że błąd staje się w pewnych wypadkach drogą do prawdy i to jedyną drogą. Co więcej, często zdarza się tak, że nie jest dane jednemu człowiekowi doczekać końca jakiegoś badania; jest to bowiem proces nie tylko wielu etapów, lecz także wielu umysłów. Co jeden zaczyna, drugi dokończy, a prawdziwy wniosek przychodzi nie od razu, wypracowany przez współdziałanie niezależnych szkół naukowych i wytrwałość kolejnych pokoleń. Skoro rzeczy tak się mają, jesteśmy obowiązani w naszych okolicznościach zgodzić się chwilowo z tym, w czym wyczuwamy błąd, mając wszakże na uwadze tę prawdę, która się $\mathrm{z}$ niego ostatecznie wyłoni.

Nasuwa się tu szczególnie analogia do przenoszenia się z miejsca na miejsce. Nikt nie wdziera się na wierzchołek góry linią prostą, żaden żaglowiec nie dociera do portu bez lawirowania. Tak więc, stosując takie porównanie, możemy rzeczywiście, jeśli tak zechcemy, odmówić w ogóle naszej zgody na badania czy dociekania naukowe, lecz jeżeli wciągamy rozum w jego rolę w naszych szkołach, to wedle sprawiedliwości musimy pozwolić mu działać w pełni i swobodnie. Jeżeli rozumujemy, musimy przyjąć warunki, które rozum stawia. Nie możemy działać połowicznie. Musimy używać rozumu jako że pochodzi od Tego, który dał nam również Objawienie. Gdy jednak wciąż przerywamy rytm działania rozumu i skierowujemy jego uwagę ku obiekcjom zaczerpniętym z wyższej wiedzy, to zachowujemy się jak szczur lądowy, stropiony zmianami kursu statku, na który wsiadł, choć był świadomy tego, co robi, mimo że nie raz okazujemy stanowczo pewien brak zaufania już to do władz rozumu, już to do pewności, która cechuje objawioną Prawdę i jej się należy. Pasażer nie powinien był w ogóle wsiadać na okręt, jeżeli się nie liczył z ewentualnością wzburzonego morza, prądów, wichrów i przypływów, skał i ławic. Postąpilibyśmy mądrzej, gdybyśmy się w ogóle odrzekli rozumu, niż okazując wielkie zaniepokojenie i zniecierpliwienie w obliczu stanu niepewności, zwłoki, niepokoju, $\mathrm{z}$ natury rzeczy towarzyszące używaniu rozumu. Zarzućmy świecką historię, naukę, filozofię na dobre i ostatecznie, jeżeli nie wolno nam uważać Objawienia za tak prawdziwe, że spory i zagmatwania ludzkich poglądów nie mogą naprawdę ani definitywnie zaszkodzić jego powadze. Nie będziemy tego uważać za triumf intelektualny religii, co nie zostało potwierdzone prżez pełne sformułowanie argumentów, które można przeciwstawić danej tezie; to nic innego, jeno „ego vapulando, ille verberando” starej komedii. 
Wielkie umysły potrzebują szerokiego, swobodnego miejsca dla swych poruszeń, zaiste nie w dziedzinie wiary, ale myśli. To samo można powiedzieć o mniejszych i o wszelkich umysłach. Jest w świecie wiele osób zwanych geniuszami i to z niemałą dozą prawdy. Natura obdarzyła je jakąś szczególną zdolnością lub bystrością w jakimś kierunku i jeśli ten dar gwałtownie ich podnieci i owładnie nimi z pozycji rozkazodawczej, są ślepi na wszystko inne. W zakresie własnej specjalizacji stają się entuzjastami, ale tracą wrażliwość na piękno wszelkich kierunków, oprócz własnego. Zgodnie z tym uważają swój kierunek za jedyny w świecie, którym warto się zajmować, i żywią rodzaj pogardy dla studiów w zakresie jakiegokolwiẹk innego kierunku. Otóż ci ludzie mogą być i często są dobrymi katolikami, lecz nie przychodzi im do głowy żadna postawa prócz szacunku i przywiązania do katolickości, ba - są pełni oddania dla sprawy Kościoła. Jeśli się jednak zakłada, że w swoich przemyśleniach, badaniach i wnioskach nie wystarczy, by byli ogólnie posłuszni Kościołowi i uznawali jego dogmaty za prawdziwe, ale że muszą dysponować całym zbiorem wypowiedzi teologów oraz tez religijnych, przyjętych do wierzenia przez masy, to w rezultacie - gasi się w nich ognisko myśli i zadeptuje płomień zapału, tak że w ogóle nie zdołają zrobić niczego.

To był przykład ludzi o bardzo szczególnym kalibrze uzdolnień. Dla kontrastu powiedzmy teraz słowo na temat umysłów przywódczych i potężnych, obdarzonych szerokim, filozoficznym spojrzeniem na rzeczy oraz twórczym pierwiastkiem i elastycznością, która potrafi się dostesować do różnych dziedzin myśli. Takie osoby podejmują ewentualnie jakąś ideę i skupiają na niej swoją duchową energię; może to być idea głęboka, płodna, otwierająca wielkie problemy, która wrasta w ich myślenie, aż rozbudują ją w wielki system. Otóż jeżeli jakiś taki myśliciel zaczyna od radykalnie mylnych zasad albo zmierza do wprost fałszywych wniosków końcowych, czy będzie to Hobbes, Shaftesbury, Hume czy Bentham, wtedy od razu jest po wszystkim. Taki czlowiek to przeciwnik Prawdy Objawionej i zamierza nim pozostać. Nie ma tu nic więcej do dodania. Może jednak rzecz nie ma się tak właśnie, może jego błędy należą do tych, których nie da się oddzielić od przypadłości jego systemu albo jego umysłu i rozwinęły się spontanicznie, nie są zaś zaciekle bronione. Każdy ludzki osobnik, każdy człowiek, który jest pisarzem, otwiera się na sprawiedliwą krytykę. Każcie mu zamknąć teczkę z danymi o jego rozwoju. W porządku! Ale może wtedy właśnie tracicie to, co - ujmując rzecz całościowo i pomimo nieistotnych pomyłek — mogło się okazać jedną z najlepszych apologii Prawdy Objawionej (wprost albo pośrednio, zależnie od jego specjalności), jakimi świat kiedykolwiek dysponował?

Tak oto wygląda moje wytłumaczenie tej okoliczności, która czasem powodowała zdziwienie, że tylu wielkich myślicieli katolickich naraziło się pod tymi czy innymi względami na krytykę lub niechęć teologów albo władzy kościelnej. Tak musi być w istocie rzeczy. Istnieje rzeczywiście stanowisko nieprzychylne, 
implikujące potępienie autora, ale też istnieje inne, które znaczy nie więcej niż formuła „pie legendum”, wypisana przy określonych tekstach Ojców Kościoła. Nie musi to stanowić krytyki autora, a jednak władza kościelna zasługiwałaby na krytykę, gdyby nie zwróciła uwagi na niedoskonałości tegoś autora. Nie wiem, jaki katolik mógłby nie okazać czci nazwisku Malebranche'a, a przecież mógł on wpaść pomimo to przy jakiejś sposobności w niezamierzoną kolizję z teologami, albo posunąć się do zbyt śmiałych twierdzeń. Praktyczne pytanie brzmi: czy nie lepiej się stało, że pisał tak, jak pisał, niż gdyby nie był pisal wcale?

Stolica Swięta nawykła do trzymania się tego rodzaju stanowiska do tego stopnia, że zajmowała je w stosunku do autorów nie tylko filozoficznych, lecz również teologicznych i kościelnych, nie wchodzących w zakres niniejszych uwag. Sądzę, że trafnie oceniam, iż tak się miała rzecz w przypadku trzech wielkich autorów dzieł o różnej uczoności: kardynała Norisa, Bossueta i Muratoriego. Nie ukrywając, że każdy z nich wysunął twierdzenia, które mogły zostać lepiej sformułowane, to jednak według oceny Kościoła ich zasługi dla religii były, ogólnie mówiąc, zbyt ważne, by należało ich gnębić przez krytykę szczegółów.

\section{VIII}

A teraz, moi Panowie, dochodzę do końcowego wniosku niniejszych uwag. To, co zalecałbym mocno każdemu, bez względu na kierunek jego badań naukowych, co zalecałbym ludziom nauki w ich myślach o teologii, co ważyłbym się rekomendować teologom, gdy uwaga ich zwróci się w kierunku badań naukowych — to jest tym wielka i mocna wiara w suwerenność Prawdy. Błąd może przez jakiś czas mieć powodzenie, ale Prawda na końcu zwycięży. Jedynym skutkiem błędu jest ostateczne poparcie Prawdy. Teorie, rozważania, hipotezy bywają puszczane w obieg. Może ich przeznaczeniem jest obumarcie, lecz nastąpi to nie wcześniej, aż zrodzą coś lepszego od siebie.

Te lepsze idee zostaną z kolei podjęte przez innych ludzi, a jeśli nie prowadzą do prawdy, to prowadzą do czegoś, co jest prawdy bliższe niż one same. W ten sposób następuje postęp w wiedzy jako całości. Błędy pewnych umysłów w badaniu naukowym są bardziej owocne niż prawdy innych. Wydaje się, że nauka nie czyni postępów, natomiast obfituje w potknięcia, a mimo to niedostrzegalnie posuwa się naprzód i przynosi korzyść prawdzie nawet, gdy się dowiadujemy, co nie jest prawdą, jeżeli już niczego więcej.

Poza tym należy pamiętać, proszę Panów, że cały czas zakładam dobrą wiarę, uczciwe intencje, katolickiego ducha lojalności i głębokie poczucie odpowiedzialności. Zakładam w badaczu naukowym należytą obawę, by nie dać powodu do zgorszénia, by nie stworzyć pozoru, że się aprobuje coś, czego się na- 
prawdę nie aprobuje, że stoi się po stronie tych, od których zasadniczo różni się przekonaniami. Zakładam, że nasz badacz $\mathrm{w}$ pełni zdaje sobie sprawę z istnienia i siły współczesnej niewiary; że jest świadom moralnej słabości i intelektualnego zamięszania u większości ludzi; że zgoła nie pragnie, by którakolwiek pojedyncza dusza miała ponieść szkodę w zetknięciu się z pewnymi, szerzącymi się dziś spekulacjami, choć może czerpać satysfakcję z pewności, że spekulacje te, jako błędne lub źle rozumiane, zostaną sprostowane w trakcie najbliższego półwiecza. 